\title{
Skutki ,pomarańczowej rewolucji” na Ukrainie i ich znaczenie w wyborach prezydenckich 2010 roku
}

Kwiat dzisiejszego zwycięstwa niesie w sobie kietki jutrzejszej porażki.

Przysłowie chińskie

$\mathrm{U}$ kraina po uzyskaniu niepodległości stała się areną walki dwóch obozów: prozachodniego i prorosyjskiego. Walka ta ma na celu podzielenie sfery wpływów w Europie Wschodniej, postrzeganej od 1945 r. jako obszar oddziaływań sowieckich ${ }^{1}$. Rosja chce utrzymać kontrolę nad Ukrainą nie tylko ze względu na więzi historyczne i kulturowe, które łączą oba państwa, ale ze względu na poczucie bezpieczeństwa dawnego imperium, które staje się coraz bardziej izolowane na arenie międzynarodowej ${ }^{2}$. Stany Zjednoczone i Europa Zachodnia angażują się w politykę wzmacniania niepodległości Ukrainy, oddalając ją tym samym od wpływów Rosji. $Z$ tego też powodu polityka zagraniczna Ukrainy jest ciagłym balansowaniem pomiędzy zachodnim a wschodnim partnerem ${ }^{3}$. Momentem dziejowym w obieraniu kierunku rozwoju państwa są zawsze wybory parlamentarne czy prezydenckie. Wybory prezydenckie na Ukrainie z 2004 r. można uznać za jedne z najbardziej dramatycznych, albowiem zasiały one ziarno nadziei w ludzkich sercach.

Celem artykułu jest prześledzenie wydarzeń przełomowych w najnowszej historii Ukrainy, a więc przebudzenie społeczeństwa obywatel-

1 J. Kłoczowski, Europa Środkowo-Wschodnia i jej miejsce w Europie, „,Rocznik Instytutu Europy Środkowo-Wschodniej” 2007, nr 5, s. 11-32.

2 M. Słowikowski, Rosja wobec Europejskiej Polityki Sasiedztwa Unii Europejskiej, „Rocznik Instytutu Europy Środkowo-Wschodniej” 2008, nr 6, s. 85-101.

3 R. Miler, Ukraina po pomarańczowej rewolucji-szanse i zagrożenia, http://dlibra.sbc.katowice.pl/Content/5402/ukr_1_art.pdf, 2005. 
skiego, wyrażającego się w postaci protestów na Majdanie Niepodległości pod koniec 2004 r. Analizując konkretne założenia „pomarańczowej rewolucji” ze strony prawnej i socjologicznej, wskażemy na poziom ich realizacji oraz będziemy doszukiwać się prawdopodobnych przyczyn ich niepowodzeń. Przedstawione zostaną również psychologiczne mechanizmy, które kryły się za masowym powstaniem ludności. Na koniec przybliżymy znaczenie i rolę ,pomarańczowej rewolucji” w wyborach prezydenckich $2010 \mathrm{r}$.

\section{Próby zrozumienia ,pomarańczowej rewolucji”}

Początek XXI w. odznaczył się serią „kolorowych rewolucji”: od „rewolucji” 2000 r. w Jugosławii, „rewolucji róż” w Gruzji, poprzez ,pomarańczową rewolucję” na Ukrainie, do „rewolucji tulipanów” w Kirgistanie. Doświadczenie każdej z nich stanowiło przykład dla następnej. Jeśli pod koniec XX w. celem „rewolucji” we Wschodnich Niemczech, Bułgarii i Czechosłowacji było odrzucenie reżimu komunistycznego, to „kolorowe rewolucje" miały za zadanie przełożyć ścieżkę demokracji w już pokomunistycznych państwach. Proces transformacyjny po upadku Związku Radzieckiego zaczęty demontażem starych struktur nie był bowiem wspierany rozbudową nowych. Zarządzanie państwem należało (lub po niedługim czasie przeszło z braku opozycji) do komunistycznej nomenklatury, która używając demokratycznych haseł kontynuowała realizowanie planów minionej epoki ${ }^{4}$. Pojęcie „rewolucji” jest szeroko używane dla określenia zmian społecznych, jak również w dziedzinach nauki, technologii, przemysłu, kultury. Myśl teoretyczna rewolucji bierze początek z historiozoficznej i socjologicznej tradycji intelektualnej. Obecnie w literaturze przedmiotu można znaleźć wiele definicji łączących podstawowe idee obu tych tradycji. W celu jednoznacznego określenia, co się kryje pod rzeczownikiem „rewolucja”, na początku podamy cechy wspólne dla niektórych definicji. Tak więc, mówiąc o rewolucji politycznej mamy na myśli fundamentalną zmianę systemu politycznego (lub przynajmniej elity rządzącej) w drodze przemocy, na skutek gwałtownego zaangażowania znacznej części ludności ${ }^{5}$. Biorąc pod uwagę masowość i ,wybuchowość”, w stosunku do wy-

4 О. Романюк, Посткомуністичні революиії, „Політичний менеджмент” 2005, nr 4, s. 16-28.

5 P. Sztompka, Socjologia Analiza społeczeństwa, Kraków 2007, s. 541-542. 
darzeń listopada-grudnia 2004 r. na Ukrainie można by było użyć pojęcia rewolucja, jednak wchodząc w szczegóły i analizując zaszłe zmiany z perspektywy pięciu lat, należy zastanowić się nad słusznością tego określenia.

Z przeprowadzonej przez J. Macijewskyego syntezy myśli ukraińskich i światowych intelektualistów na temat „pomarańczowej rewolucji” wynika, że większość z nich uznaje ją jako rewolucję lub przynajmniej jako pewien etap „ukraińskiej rewolucji”. Rozpatrują oni rewolucję w bardzo szerokim znaczeniu, jako symbol zmian w ważnych sferach życia społecznego. Takie traktowanie budzi nasze wątpliwości odnośnie do prawidłowości wykorzystania tego terminu. J. Macijewskyj uważa, że już same wybory prezydenckie, podczas których odbywały się protesty, dyskwalifikują uznanie wydarzeń 2004 r. jako rewolucyjnych. Przytacza także takie cechy rewolucji jak: ciagłość procesu oraz mobilizację wszystkich warstw społecznych, w szczególności najmniej bogatych, dowodząc, że trudno jest traktować ,pomarańczową rewolucje” jako rewolucję w pełnym sensie tego słowa ${ }^{6}$. Z kolei W. Malynkowycz sądzi, że celem prawicowej opozycji nie były dogłębne systemowe zmiany ustroju państwa (jedna z kluczowych oznak rewolucji), lecz zmiana elity rządzącej. Jego zdaniem „pomarańczową rewolucję” warto nazwać kryzysem politycznym, gdyż nie spełnia ona podstawowego warunku rewolucji ${ }^{7}$.

Jeszcze jednym aspektem godnym uwagi jest charakterystyczne dla tej „rewolucji” zachowanie norm moralnych i konstytucyjnych, kierowanie się wyłącznie ideologią rewolucji. Nie skończyło się również na pozbawieniu wolności przedstawicieli „starej” władzy, nawet odwrotnie - znalezieniem kompromisów ${ }^{8}$. Historia pokazuje (1989 r. w Europie Środkowej i Wschodniej, za wyjątkiem Rumunii), że przy sprzyjających warunkach geopolitycznych możliwe jest wprowadzenie zasadniczych zmian z zaangażowaniem znacznej liczby mas drogą pokojową ${ }^{9}$. W taki sposób zmiana władzy bez interwencji zbrojnej, jak uważa O. Romaniuk, kwalifikuje „pomarańczową rewolucję” jako „aksamitną”. J. Macijewskyj jednak nie zgadza się z takim myśleniem i uważa „pomarańczową

6 Ю. Мацієвський, „Помаранчева революиія” крізь призму міждисциплінарних сочіальних досліджень, „Політичний менеджмент” 2005, nr 6, s. 7-22.

7 В. Малинкович, О причинах Оранжевой Революччи в Украине, http://www.igpi.ru/monitoring/ukraine/new_ukr/revolution/1118840376.html, 2005.

8 С. Грабовський, Так революичія!, „Українська правда” 2005, 24 січня, http://www.pravda.com.ua/articles/2005/01/24/3006418/.

9 Sztompka, op. cit., s. 541-542. 
rewolucje” jako pewne „przejście”, tzn. taki typ politycznej transformacji, dla którego charakterystyczna jest zmiana instytutów państwowych w ramach prawa.

Uważamy, że dogłębne zmiany w ekonomicznej, politycznej i kulturalnej sferze życia społecznego są procesem trwałym. Uwzględniając wszystkie wyżej wymienione aspekty zgadzamy się z poglądem, że ,pomarańczowa rewolucja” 2004 r. wraz z ,rewolucja na granicie” 1990 r., akcją „Ukraina bez Kuczmy”, uchwałą Konstytucji 1996 r., razem stanowią proces nowożytnej ukraińskiej rewolucji ${ }^{10}$. Tak więc „pomarańczowa rewolucja" jest kolejnym etapem ewolucji społeczeństwa Ukrainy na drodze do demokracji.

U G. Kasjanowa można znaleźć kilka wersji powstania „pomarańczowej rewolucji”. Każda z nich opiera się na kategoriach, pozbawionych ideologicznego zabarwienia i tym samym odzwierciedla odpowiednie widzenie uczestników i obserwatorów. Zgodnie z pierwszą wersją „rewolucja" była oczekiwanym rezultatem poprzedniego rozwoju państwa. Wybuch aktywności społecznej spowodowany był wzrastającym niezadowoleniem z „reżimu Kuczmy” oraz beztroskim zachowaniem władzy. Trudno jednak mówić o „pomarańczowej rewolucji” jako efekcie zachodzących prawidłowości ewolucyjnych, gdyż była ona zbiorem spontanicznych reakcji, zbiegu okoliczności i przypadków, planów i nieoczekiwanych ich skutków. Skrajną formą wyobrażenia tej wersji jest manipulacja świadomością mas oraz organizowanie protestów przy pomocy środków finansowych zachodnich państw ${ }^{11}$.

Druga wersja łączy się z pierwszą i mówi o ,powstaniu milionerów przeciwko miliarderom”. Na Ukrainie polityka i biznes są mocno połączone, dlatego wybory nie są walką ideologii, tylko walką struktur biznesowych o zakres wpływu na politykę dla zabezpieczenia dogodnych warunków $^{12}$. Milionerzy, niezadowoleni z sytuacji, w której tylko kilka „klanów oligarchicznych” ma dodatkowe ulgi i przewagę w prowadzeniu biznesu, wynikające z ,układów” z władzą, stworzyli projekt wyborczy dla swojego kandydata. Inteligentny, porządny, ugodowy „bohater narodowy" - W. Juszczenko idealnie pasował na tę rolę. W momencie, gdy

10 С. Грабовський, op. cit.

11 Г. Касьянов, Україна 1991-2007: нариси новітньої історії, Київ 2007, s. $346-353$.

12 О. Кіндратець, Розмежування українського суспільства в проиесі демократизації, „Політичний менеджмент” 2005, nr 6, s. 32-41. 
w sposób naturalny W. Juszczence nie udało się objąć fotelu prezydenta, ludzie z nim powiązani sprowokowali masowe protesty, finansując ich organizację. Jest to dość prawdopodobne, ale tylko jako jeden aspekt wydarzeń ukraińskich 2004 r.

Następna wersja równoważy instrumentalizm i wichrzycielstwo z poprzedniej, koncentrując się na przebudzeniu świadomości politycznej ludności na skutek masowych przekrętów i fałszerstw podczas wyborów. Majdan odzwierciedlił złączenie narodu ukraińskiego, jego patriotyzm, świadomość i wartości demokratyczne ${ }^{13}$. Zgodnie z tą wersją, zaprzecza się celowemu planowaniu akcji i manipulowaniu świadomością obywateli. Twierdzenie o poparciu rewolucji przez „klasę średnią” odpowiada rzeczywistości, dlatego że w Kijowie, gdzie odbyły się protesty ludności, skupia się przeważna część ukraińskiej „klasy średniej”.

Wersja czwarta mówi o czynnikach zewnętrznych, mianowicie o walce „Wschodu” i ,Zachodu” o wpływ na Ukrainę. Rosja nie ukrywała swojego poparcia dla kandydata „starej władzy”, mając plany stworzenia jednej ekonomicznej przestrzeni, łączącej Rosję, Ukrainę, Białoruś i Kazachstan. W takim związku pełniłaby ona główną rolę z racji posiadania największych zasobów ekonomicznych ${ }^{14}$. Z kolei Stany Zjednoczone działające w ramach programu obrony praw człowieka Freedom House Support Act („Dom Wolności”), stawiały na formowanie społeczeństwa obywatelskiego i jego aktywności politycznej na Ukrainie. W raporcie organizacji z kwietnia 2004 r. podkreślono, że w przypadku gdy na Ukrainie nie będą respektowane wartości demokratyczne i prawne, jej integracja z europejskimi strukturami międzynarodowymi i wspólnotą państw demokratycznych będzie odłożona w czasie ${ }^{15}$. Rosja przegrała tę walkę, stawiając na marketing polityczny i nie biorąc pod uwagę czynnika wewnętrznego. Ukraina już nie chciała powrotu czasów komunistycznych, większa część społeczeństwa opowiedziała się za demokratycznym „Zachodem”, a więc za Juszczenką ${ }^{16}$.

Wersja piąta, zgodnie z którą rosyjskojęzyczny wschód i południe państwa i rolny zachód, to dwie różne „Ukrainy”. Odwołując się do faktów historycznych, specjaliści od marketingu politycznego głośno dyskutowali

13 З. Бжезинський, В Україні-вибух самосвідомості, „День” 2004, 4 грудня.

14 В. Малинкович, ор. cit.

15 Freedom House пишет о темниках и опасности политреформы, ,Зеркало Недели" 2004, nr 14, 10-16 апреля, http:/www.zn.ua/1000/1550/46167/.

16 В. Малинкович, op. cit. 
o kulturalno-regionalnych różnicach w kraju w okresie wyborów prezydenta w 2004 r. Wykorzystali ten aspekt dla pokazania rozłamu państwa na dwie Ukrainy: „Zachodnioeuropejską” oraz „Euroazjatycką" ${ }^{\prime 7}$. Natomiast badania socjologiczne podają że istnieje coraz mniej problemów z samoidentyfikacją obywateli Ukrainy, niezależnie od języka, religii czy przynależności etnicznej. Należałoby powiedzieć o aksjologicznym rozłamie Ukrainy, a nie o rozłamie narodowym. Rozłam aksjologiczny miałby wynikać z historycznej przynależności jej części do różnych krajów, dla których charakterystyczna jest odmienna kultura polityczna i społeczna ${ }^{18}$.

Wersja szósta jest wyrażona tezą, że „rewolucja pomarańczowa” była owocem działalności specjalistów od marketingu politycznego oraz intensywnych manipulacji świadomością wyborców. Zdaniem G. Kasjanowa takie stwierdzenie jest również prawdopodobne.

Podsumowując swoje rozważania G. Kasjanow twierdzi, że wydarzenia z listopada-grudnia 2004 r. na Ukrainie nie mogły być wynikiem jednej przyczyny. Podzielając zdanie autora, uważamy, że „pomarańczowa rewolucja" była wywołana szeregiem okoliczności społeczno-politycznych, uwarunkowanych procesem ewolucyjnym ostatnich dziewiętnastu lat. Poniekąd „rewolucja pomarańczowa” łączyła w sobie zaplanowaną mobilizację masowego oburzenia i organizację akcji niezadowolenia oraz spontaniczną reakcję ludności na niesprawiedliwość.

\section{Zmiany wewnątrzpaństwowe po „pomarańczowej rewolucji”}

Głównym osiagnięciem ,„pomarańczowej rewolucji”, nazywanej jeszcze „rewolucją w głowach”, było narodzenie świadomości narodowej, woli politycznej, jakościowa zmiana prawnej kultury całego społeczeństwa. Okres, który staramy się przeanalizować, można scharakteryzować jak czas postępu demokratycznego. Dojście do władzy ugrupowania opozycyjnego na czele z W. Juszczenką było możliwe dzięki „kredytowi zaufania”, który otrzymali oni od społeczeństwa. Tak zwana rewolucja „wyniosła" na najwyższe stanowisko w państwie wybranego zgodnie z wolą narodu lidera, co z kolei było gwarantem, że obiecywane przez niego reformy zostaną podtrzymane. Przeanalizujemy wyniki działalności

17 Ibidem.

18 М. Михальченко, Цивілізаційна чи иіннісна розколотість Украӥни?, „Політичний Менеджмент" 2006, nr 6, s. 18-28. 
W. Juszczenki, aby móc ocenić jego osiagnięcia, znaleźć przyczyny niepowodzeń i spróbować antycypować możliwości dalszego rozwoju sytuacji w państwie.

Fundamentalnym dokumentem programowym W. Juszczenki w kampanii wyborczej na prezydenta w 2004 r. był tak zwany plan działalności W. Juszczenki „Dziesięć kroków naprzeciw ludziom”. Plan ten składał się z następujących pozycji: 1) stworzenie $5 \mathrm{mln}$ miejsc pracy. Według danych Państwowego Komitetu Statystyki na Ukrainie, poziom bezrobocia ludności w wieku produkcyjnym w $2005 \mathrm{r}$. wynosił 7,8\%, a pod koniec 2009 r. $-9,6 \%$. Na koniec prezydentury Juszczenki zaobserwowano niewielki wzrost bezrobocia ${ }^{19}$; 2) zabezpieczenie priorytetowego finansowania programów społecznych. W tej sferze działalności udało się osiagnąć pożądane rezultaty: po raz pierwszy za lata niepodległości Ukrainy zwiększono pomoc finansową dla rodziców podczas narodzenia dziecka. Demografowie i dzisiaj odnotowują pozytywny wpływ prorodzinnej polityki. Wyniki sondaży z ostatnich trzech lat wskazują na zwiększenie liczby kobiet, które zrezygnowały z budowania swojej kariery na rzecz dbania o własną rodzinę; 3) zwiększenie budżetu państwa kosztem zmniejszenia podatków. W $2006 \mathrm{r}$. wnoszone projekty ustaw były zgodne z programem kampanii wyborczej - praca nad tworzeniem modelu ekonomii społecznej, a więc udoskonalenie systemu podatkowego, poprawa klimatu inwestycyjnego, stworzenie równych warunków dla działalności ekonomicznej. Projekty ustaw o minimalizacji podatku dla małych i średnich przedsiębiorstw były wnoszone do parlamentu, jednak nie zostały przyjęte. Było to spowodowane niemożnością zebrania odpowiedniej liczby głosów wśród byłych sprzymierzeńców „rewolucji” i niezdolnością przekonania opozycji ${ }^{20}$; 4) zmuszenie władzy do pracy dla ludzi, walka z korupcją. Zostały przyjęte aż dwie antykorupcyjne ustawy. Nie zbadano jednak żadnej kryminalnej sprawy, chociaż sprawa antykuczmowskiego dziennikarza G. Gongadze lub sprawa otrucia samego Juszczenki były obietnicą numer 1 w kampanii przedwyborczej; 5) stworzenie bezpiecznych warunków życia dla społeczeństwa. Chodziło m.in. o walkę ze zorganizowaną przestępczością, ochronę przed ekologicznymi katastrofami; 6) zabezpieczenie wartości rodzinnych i poszanowanie praw dziecka. Jednym z realizowa-

19 Державний Комітет статистики України, Основні показники ринку пращуі (річні дані), http://www.ukrstat.gov.ua/, 2010.

20 О. Носова, Аналіз законотворчої роботи партій, щзо прийшли до влади в наслідок виборів 2006 року, „Збірник аналітичних висновків” 2007, s. 206. 
nych zadań było wprowadzenie instytucji lekarza rodzinnego, zauważalna jest również tendencja do aktywnego rozwoju domów dziecka rodzinnego typu. Nie został jednak wprowadzony program młodzieżowego kredytowania hipotecznego; 7) sprzyjanie duchowieństwu, wzmocnienie moralnych wartości. Prezydent zaangażował się w sprawę uznania ludobójstwa ukraińskiego narodu - głodu 20-30 lat - przez światową opinię społeczną. W ten sposób próbował on zjednoczyć dwie części Ukrainy, na które została ona medialnie podzielona przez specjalistów od marketingu politycznego w czasie kampanii wyborczej; 8) sprzyjanie rozwojowi ukraińskiej wioski. Pomimo zakazu sprzedaży gruntów rolnych w celu obrony praw rolników, ziemie te są nadal sprzedawane. Brak perspektyw życia na wsi powoduje migracje młodzieży do dużych miast; 9) zwiększenie finansów na potrzeby wojska, zmiana postaw wobec osób noszących mundury wojskowe. W 2005 r. była zlikwidowana Państwowa Autoinspekcja, wskutek czego 7000 osób straciło pracę, a bezpieczeństwo na drogach znacznie się pogorszyło. Dokonano częściowych reform w armii: zmniejszono okres służby, zwiększono ilość miejsc pracy dla zawodowych żołnierzy. Finansowanie armii pozostało na niedostatecznym poziomie; 10) prowadzenie polityki zewnętrznej, której celem będzie dbanie o interesy narodu ukraińskiego. Juszczenko aktywnie popularyzował ideę wejścia Ukrainy do Unii Europejskiej i NATO. Jeśli akcesja do UE zyskała akceptację ludności, to wstąpienie do struktur Paktu Północnoatlantyckiego budziło wiele podejrzeń i niepewności. Niewątpliwie wydarzenia z 2004 r. spowodowały, że Ukraina zaistniała na arenie międzynarodowej, ale kryzys polityczny przyniósł niestabilność ekonomiczną, zmniejszając tym samym atrakcyjność inwestycyjną. Na drodze wejścia do UE nie ma istotnych postępów, a polityka wizowa w niektórych ambasadach znacznie się skomplikowała.

Podczas ,pomarańczowej rewolucji” dokonała się bardzo ważna zmiana w konstytucji Ukrainy. Została przeprowadzona reforma, na skutek której system państwa prezydencko-parlamentarnego zmienił się na parlamentarno-prezydencki ${ }^{21}$. Innymi słowy ograniczono władzę prezydenta, nadając ją z kolei Gabinetowi Ministrów Ukrainy (GMU) i Radzie Najwyższej Ukrainy (RNU). GMU mianowano najwyższym organem władzy wykonawczej.

21 R. Miler, op. cit. 
Należy zauważyć, że w większości programów przedwyborczych kandydatów na prezydenta w 2010 r. były poruszane kwestie reformy konstytucyjnej. Można to wyjaśnić faktem, że w ostatnich latach konstytucja stała się przedmiotem częstych dyskusji i sprzeczek. Ogólny programowy charakter konstytucji i jej defekty prawne stały się dobrym fundamentem dla manipulacji różnych sił politycznych. Właśnie w czasie prezydentury Juszczenki znacznie zwiększyła się rola Sądu Konstytucyjnego, jako jedynej instytucji, która reguluje podstawowe prawo. O ile Sąd ten znajduje się pod wpływem prezydenta, mamy podstawy uważać go za potencjalny polityczny instrument. Projekt nowej konstytucji wniosła już partia aktualnego prezydenta Ukrainy. Tendencja do zmiany prawa podczas wyborów była zauważalna i w tym roku. W okresie pomiędzy turami wyborów zostały wniesione zmiany do ustawy „O wyborach prezydenta”. Analiza prawa wyborczego w okresie 2004-2010 daje podstawę do stwierdzenia o zmniejszeniu demokratyczności i przejrzystości wyborów. W 2004 r. wniesiono zmiany z następującymi poprawkami, które dotyczyły wyborów parlamentarnych: większościowo-proporcjonalny system zamieniono na proporcjonalny, listy partyjne zostały zamknięte. Charakterystycznym dla ukraińskich wyborów jest częsta zmiana prawa wyborczego w przeddzień samych wyborów przez większość parlamentarną na korzyść kandydata ze strony władzy. Taka niestabilność prawnego systemu rzutuje swoje negatywne skutki praktycznie natychmiast. Warto wyakcentować to, że „pomarańczowa rewolucja” znacząco wpłynęła na instytucje wyborcze na Ukrainie. Jakościowa zmiana procesu wyborczego - niwelowanie administracyjnego wpływu, zmniejszenie liczby falsyfikacji - socjolodzy i prawnicy nazywają jednym z największych osiągnięć „rewolucji”.

„Pomarańczowa rewolucja” spowodowała zmianę wizerunku Ukrainy na lepsze $^{22}$. „Ukraina udowodniła ponad wszelką wątpliwość że jest krajem europejskim - nie tylko w sensie geograficznym, lecz także co najważniejsze, pod względem przywiązania do najważniejszych wartości demokratycznych"23. Spory polityczne, które miały miejsce po „pomarańczowej rewolucji” są efektem ubocznym demokracji. Pod tym względem nie obserwujemy porażki rewolucji, bo pluralizm i wolność wyboru są istotą

22 J. Urbanowska, W. Oniszczuk, Ukraina - przewodnik dla przedsiębiorców, Warszawa 2006, s. 18.

23 J. Liczner, Po rewolucji pomarańczowej. Relacje UE - Ukraina do wiosny 2006 roku, http://www.batory.org.pl, 2006, s. 7. 
rewolucji ${ }^{24}$. Być może realizacja obietnic z Majdanu byłaby skuteczniejsza, gdyby nie rywalizacja, która rozpoczęła się pomiędzy J. Tymoszenko a otoczeniem W. Juszczenki. Pierwszą „kością niezgody” był kryzys energetyczny, podczas którego Tymoszenko oskarżyła rosyjskich eksporterów o specjalne podwyższanie cen, aby zdestabilizować sytuację na Ukrainie. Juszczenko był innego zdania i obwinił za to $\mathrm{rząd}^{25}$.

Do pozytywnych zmian, które nastapiły po wydarzeniach zimy $2004 \mathrm{r}$. możemy zaliczyć także przebudzenie społeczeństwa obywatelskiego. Od rozpadu Związku Radzieckiego po raz pierwszy można było zaobserwować takie masowe niezadowolenie z władzy. U przeciętnego obywatela zniknął strach przed braniem udziału w demonstracjach (który towarzyszył mu od czasów komunistycznych). Masowa integracja ludzi wokół jednej idei stała się dobrym gruntem dla nowego kierunku rozwoju ukraińskiego narodu. Stan spraw w sferze wolności słowa polepszył się, znikły tak zwane „temnyky” - zamawiane przez administrację prezydenta reportaże radiowe i telewizyjne, zapoczątkowane w 2001 r., które podawały niepełną albo nieobiektywną informację, za pomocą której tworzono przychylny wizerunek obozu rządzącego. Opozycja zaczęła faktycznie wpływać na procesy w państwie.

Istnieje pogląd, że społeczeństwo ukraińskie nie było gotowe ani instytucjonalnie, ani psychicznie do potwierdzenia swoich zawyżonych oczekiwań. Ludzie naiwnie oczekiwali, że po dojściu do władzy nowej politycznej siły uda się w krótkim czasie pozbyć się „,chorób” dziedziczonych przez lata. Oszustwo uczestników „rewolucji” odbiło się negatywnie na narodowej identyfikacji. Chaos i stagnacja pomimo swych negatywnych skutków spowodowały, że odchodzi się na Ukrainie od modelu postkomunistycznych prezydenckich reżimów na rzecz polityki kompromisowego porozumienia $^{26}$.

Spoglądając na Ukrainę po pięciu latach od wydarzeń na Majdanie, można stwierdzić, że synonimami „pomarańczowej rewolucji” są nie

24 W. Jarzyński, Ukraina przed wyborami i 5 lat po „Pomarańczowej Rewolucji”. Gdzie jest $i$ dokad zmierza?, http://www.mojeopinie.pl/ukraina_przed_wyborami i_5 lat po pomaranczowej_rewolucji gdzie jest i dokad_zmierza,3,1259148251, 2009 .

25 M. Przełomiec, Pomarańczowa Lady - Julia Tymoszenko. Królowa Majdanu, w: Ukraina na zakręcie. Drogi i bezdroża pomarańczowej rewolucji, red. T. Kruszona, Warszawa 2005, s. 31-49.

26 О. Ткаченко, Розбудова України після Помаранчевої революиії, „Персонал” 2007, nr 3, s. 18-23. 
tylko demokratyzacja, wolność słowa, ale i z drugiej strony - największe rozczarowanie państwa. Sprzyjały temu niespodziewane, często nieefektywne działania rządzących, brak odpowiedzialności. W czasie prezydentury W. Juszczenki istniały trzy centralne organy władzy wykonawczej, które dublowały te same pełnomocnictwa. Prowadziło to do tego, że żaden z nich nie brał odpowiedzialności za sytuację w państwie. Zgodnie z Konstytucją Ukrainy, głównym organem wykonawczym jest Gabinet Ministrów Ukrainy. Nowy prezydent stworzył Sekretariat - administracyjny organ prezydenta ${ }^{27}$ i niedługo po wyborach 2004 r. był sformowany trzeci organ - Narodowa Rada Bezpieczeństwa i Obrony.

Wewnątrzpartyjne sprzeczki stłumiły duży polityczny potencjał budowany na Majdanie. Głównym problemem pozostaje degradacja aparatu urzędników państwowych, która przenika cały pion władzy. Przyjście nowego proeuropejskiego lidera mimo oczekiwań i przedwyborczych obietnic nie rozwiązało problemu z biurokratyzacją systemu politycznego. Wzrósł poziom korupcji, jak również wzrosła liczba pracowników administracyjnych, szczególnie w centralnych regionach kraju. Według danych Transparency International za ostatnie lata, wśród 180 krajów Ukraina zajęła w 2007 r. - 118 i w 2009 r. - 146 miejsce, biorąc pod uwagę poziom korupcji (im wyższe miejsce, tym większy poziom korupcji) ${ }^{28}$.

W czasie prezydentury W. Juszczenki pojawił się nowy termin - „kumostwo" (nepotyzm), czyli faworyzowanie rodziny i znajomych przy obsadzaniu wysokich stanowisk państwowych. Problem profesjonalizmu i lojalności państwowych urzędników wymaga systemowych zmian, czasu i głębokich przemian społeczno-moralnych. Nie została przeprowadzona reforma sądownictwa, o której było tak głośno przed wyborami. Obietnice walki z korupcją w sądach i z ich uniezależnieniem pozostały obietnicami. Instytucje ochrony praw człowieka nie rozpowszechniły się i nie zyskały autorytetu, co implikuje niemożność ich wpływu na stan przestrzegania praw człowieka. Problemem pozostaje stworzony na potrzeby polityków podział Ukrainy na Wschód i Zachód. Rozkwit populizmu osiagnął swoje apogeum. Znany ukraiński socjolog, W. Fesenko zauważył, że rozliczenie za niewykonanie przedwyborczych obietnic istnieje: wyrazem tego jest ranking przychylności do W. Juszczenki, który od dnia objęcia władzy

27 R. Miler, op. cit.

28 Н. Коваленко, О. Лащенко, Україна - серед „,світових лідерів” за рівнем корупиї, Радіо Свобода, http://www.Radiosvoboda.org/content/article/1972544/html, 2010 . 
prezydenta obniżył się z 50\% do 3\%. Wielka polityka zmieniła się ze sfery zarządzania i walki o władzę w parlamencie w permanentną wojnę politycznych liderów, podobną do różnego rodzaju telewizyjnych talk-show ${ }^{29}$.

\section{Psychologiczne mechanizmy, które były odpowiedzią na próbę sfalszowania wyborów prezydenckich na Ukrainie w 2004 roku}

Powstanie ludności, nazywane często „pomarańczową rewolucją”, które miało miejsce na Ukrainie pod koniec 2004 roku należy nazwać konfliktem. Była to bowiem sytuacja, w której istniały sprzeczne motywy, cele, a także zachowania ${ }^{30}$. Psychologicznej analizy tego zjawiska można dokonać $\mathrm{z}$ wielu interesujących punktów widzenia, koncentrując się na elementach poprzedzających konflikt lub na samym konflikcie. Celem naszych rozważań będą procesy, zjawiska i uwarunkowania psychologiczne, bezpośrednio związane z eskalacją konfliktu na Ukrainie jesienią 2004 roku. Punktem czasowym, od którego zaczniemy analizę będą wydarzenia z 21 listopada, gdy W. Juszczenko zakwestionował uczciwość komisji wyborczej i wezwał naród do masowych protestów.

Konflikt ,jest procesem napędzanym zbiorowymi potrzebami i obawami, a nie całkowicie wytworem racjonalnej kalkulacji obiektywnych interesów...”31. Przyczynami konfliktów są więc nie tylko niezaspokojone podstawowe potrzeby, związane z fizjologią człowieka, ale również niezaspokojone wyższe psychiczne potrzeby takie jak tożsamość, poczucie bezpieczeństwa, sprawiedliwości. Z psychologicznego punktu widzenia, protesty odbywające się w Kijowie w 2004 roku były reakcją na poczucie niesprawiedliwości ze strony „biało-niebieskich” oraz ich kandydata na najwyższe stanowisko w państwie - W. Janukowycza. W skali masowej została zakwestionowana sprawiedliwość procedury wyboru prezydenta Ukrainy i nastąpił kryzys jego legitymizacji. Jak pisze K. Skarżyńska, poczucie niesprawiedliwości jest związane ze specyficznym poznawczym przetworzeniem doświadczenia straty czy frustracji, polegającym na znalezieniu zewnętrznego sprawcy tego doświadczenia. Jednym

29 В. Фесенко, Обидно до слёз. Что плохого и хорошего принесла Орнжевая революция?, Сейчас, www.seychas.ua/politics/2009/11/20/articles/16462.html, 2009.

30 K. Skarżyńska, op. cit.

31 H. Kelman, R. Fisher, Analiza konfliktów i ich rozwiazywanie, w: Psychologia polityczna, red. D. Sears, L. Huddy, R. Jervis, Kraków 2008, s. 288. 
z powodów poczucia niezadowolenia jest odczucie relatywnej deprywacji. Odwołując się do socjologicznego znaczenia tego terminu, chodzi o rozbieżność pomiędzy osiagnięciami jednostki a osiąnnięciami grupy odniesienia. Mogą tutaj występować porównania ,ja-inni”, ale także „my-oni”, czyli tak zwana relatywna deprywacja braterska ${ }^{32}$. Nakłada się więc na to specyficzna rola kategoryzacji społecznej, której efektem jest podział na „my” i „oni”. Podział ten, zdaniem D. Grabowskiego wynika z podstawowej zasady kolektywizmu. Odczucie relatywnej deprywacji braterskiej u zwolenników W. Juszczenki było efektem gorszego położenia swojej grupy w stosunku do grupy osób dążących do sfalsyfikowania wyników wyborów ${ }^{33}$.

Poczucie niesprawiedliwości jest przykrym stanem emocjonalnym. Ludzie podejmują wówczas działania, które mają na celu likwidację bądź zmniejszenie natężenia przykrych dyskomfortów. Działania takie w psychologii określane są jako „radzenie sobie” (coping) $)^{34}$. Potrzebę redukcji poczucia niesprawiedliwości uważać więc można za bezpośrednią przyczynę kolektywnych działań protestacyjnych na Majdanie w 2004 roku (pytaniem jest, na ile poczucie niesprawiedliwości, a na ile podsycanie tego poczucia ze strony Stanów Zjednoczonych i Europy Zachodniej stały za wydarzeniami na Ukrainie?). Za zaangażowaniem ludzi w takie działania stoi potrzeba zmiany, pokazania swojej tożsamości lub wyrażenia swoich poglądów. Nadają one znaczenie swojemu światu ${ }^{35}$.

Prawdopodobnie bez W. Juszczenki jako osoby utożsamiającej pozytywne wartości związane z demokracją i wolnością obywatelską, nie doszłoby do wydarzeń na Majdanie. Medialna kariera tego polityka zaczęła się w latach 1996-1999, gdy piastował on posadę szefa banku narodowego. Późniejsze premierostwo w latach 1999-2001 utrwaliło obraz Juszczenki jako osoby godnej zaufania i niekradnącej. Dymisja z tego stanowiska pozytywnie odbiła się na jego wizerunku. Zaczął on być postrzegany jako „przyjaciel ludu” i „wróg oligarchii”. „Nadzieje na przyszłe zmiany związano z osobą, której wizerunek kształtowały wartości preferowane przez większość narodu. A kiedy wolę tej części społeczeństwa

32 K. Skarżyńska, op. cit.

33 D. Grabowski, Psychologiczne i sytuacyjne warunkowania politycznych zachowań protestacyjnych, "Przegląd Psychologiczny” 2002, nr 2, s. 209-228.

34 Ibidem.

35 B. Klandermans, Kolektywne działania, w: Psychologia polityczna, red. D. Sears, L. Huddy, R. Jervis, Kraków 2008, s. 615-649. 
brutalnie zlekceważono, fałszując masowo wyniki wyborów, ludzie wyszli na ulice ${ }^{36}$. Należy jednak zaznaczyć, że wizerunek W. Juszczenki nie był jednoznaczny, 31\% skojarzeń zebranych w badaniach w listopadzie 2004 r. i 23\% skojarzeń z marca 2005 r. związanych z W. Juszczenką, to skojarzenia o negatywnym wydźwięku ${ }^{37}$.

Jak podkreśla G. Poczepcow, ,pomarańczowa rewolucja” była podtrzymywana przede wszystkim przez dwie klasy społeczne: młodzież i przedsiębiorców małych i średnich firm ${ }^{38}$. Dla tych dwóch grup charakterystyczne są: brak strachu, szybkie podejmowanie decyzji oraz przywiązanie do liberalnych wartości. T. Tytarenko wyróżniła cztery grupy osób ze względu na motywy, jakimi się kierowały decydując się na udział w demonstracji. Pierwszą grupę można nazwać ideologami, to są osoby najbardziej aktywne i odważne, które nie miały żadnych wątpliwości co do słuszności manifestacji. Druga grupa osób, nazwijmy ich entuzjastami, przyjechała do Kijowa niekoniecznie w celach demonstracyjnych, ale raczej żeby zobaczyć miasto, polityków i aby móc się pokazać. Kolejna grupa osób traktowała „rewolucję” jako wydarzenie, gdzie można poznać nowych ludzi, wyrazić swoje emocje. Były to osoby z dużą potrzebą poszukiwania wrażeń. Wśród protestujących byli też tacy, którzy szukali w bieżących wydarzeniach rozwiązania swoich osobistych problemów. Można przypuszczać, że w pewnej mierze motywami trzech ostatnich grup były również korzyści finansowe, które można było uzyskać demonstrując na Majdanie Niezależności ${ }^{39}$.

Z psychologicznego punktu widzenia, ludzie manifestujący swoje idee na Majdanie stanowili tłum, którego zachowanie rządzi się swoimi regułami. „Majdan fizycznie był masą: ludzie, unikający na co dzień kontaktów ze sobą, tam stali ściśnięci, tracąc cielesną indywidualność" ${ }^{40}$. T. Tytarenko pisze o powstaniu „kolektywnej psychiki”, każdy kto przebywał jakiś

36 A. Dachnij, Fenomen pomarańczowej rewolucji: wymiar historyczny i polityczno-psychologiczny, „Roczniki Międzynarodowego Centrum Kultury” 2005, nr 14, s. 21 .

М. Дроздова, Динаміка політичної свідомості студентів у процесі виборчої кампанії 2004 року, „Соціальна психологія” 2005, nr 4, s. 32-43.

38 Г. Почепцов, Оранжевые революичи и ненасильственные методы свержения власти, http://psyfactor.org/lib/or-4.htm, 2005.

39 Т. Титаренко, Революичи глазами психолога, „Зеркало недели” 2004, 18 декабря, nr 51, s. 18.

40 A. Tichołaz, Czy odbyła się na Ukrainie ,,pomarańczowa rewolucja”?, w: Etyka i polityka, red. D. Probycka, Kraków 2005, s. 426. 
czas wśród tych ludzi, zaczynał odczuwać niezwykłe potrzeby i dążenia ${ }^{41}$. Funkcjonowanie protestujących przypominało sektę, gdzie nie jest dopuszczane inne myślenie niż to, które proponuje lider ${ }^{42}$. Uduchowiony jednomyślną ideą thum stał się jednym żywym organizmem. Organizm taki jest bardzo impulsywny i podatny na szybkie zarażanie uczestników emocjami $^{43}$. Ludzie trwali w tym wyreżyserowanym przedstawieniu, mając poczucie że tworzą historię, nie biorąc pod uwagę tego, że mogą być tylko marionetkami w rękach Zachodu.

W zależności od tego, jak odbywa się proces komunikacji oraz wzajemna percepcja stron konfliktu, wyróżnia się trzy sposoby rozumienia sytuacji konfliktowej: wycofania się, kooperatywny i rywalizacyjny ${ }^{44}$. Zakwestionowanie legitymizacji władzy na Ukrainie przybrało charakter rywalizacyjny. W tym paragrafie stronimy od ewaluacji podjętych działań przez obóz „pomarańczowych”, postaramy się tylko opisać je w terminach mechanizmów psychologicznych.

Orientacja rywalizacyjna charakteryzuje się nastawieniem na realizację wyłącznie własnych celów. Strony konfliktu koncentrują się na różnicach, wartościując przy tym pozytywnie swoje elementy natomiast pejoratywnie - elementy przeciwnika ${ }^{45}$. H. Kelman i R. Fisher wyróżniają dwa procesy, uruchomienie których sprzyja eskalacji i utrwalaniu konfliktu: procesy normatywne i procesy percepcyjne. Jednym z procesów normatywnych, który można było zaobserwować podczas ,pomarańczowej rewolucji” była mobilizacja lojalności wobec grupy. „Wzbudzanie uczuć nacjonalistycznych i patriotycznych, zwłaszcza w kontekście narodowego bezpieczeństwa i przetrwania, stanowi potężne narzędzie mobilizacji poparcia publicznego"46. Procesy percepcyjne odegrały równie ważną rolę w eskalacji konfliktu. Groźnym dla obu stron konfliktu było tworzenie lustrzanych obrazów. Każda ze stron uważała się za prawą i pokojowo nastawioną, a swojego przeciwnika opisywała jako złego i wrogo nastawionego. Innymi słowy, chodzi o sytuację, w której „obie strony mają tendencje do konstruowania analogicznych obrazów siebie i innego, z wyjątkiem odwrotnych wartości" ${ }^{\text {"47. }}$

\footnotetext{
41 Т. Титаренко, op. cit.

42 Г. Почепцов, op. cit.

43 Т. Титаренко, op. cit.

44 K. Skarżyńska, op. cit.

45 Ibidem.

46 H. Kelman, R. Fisher, s. 294.

47 Ibidem, s. 297.
} 
K. Skarżyńska dodaje kolejne elementy odpowiedzialne za eskalację konfliktu ${ }^{48}$. Wspomniany już podział na „my” i „oni”, czyli tak zwana ostra kategoryzacja może powodować selektywność percepcji i pamięci. Kategoryzacja ta staje się podstawą wszelkich ocen i decyzji. W. Juszczenko obwiniał za wszystkie klęski polityki rządu ,ich”, czyli wrogów narodu, układy korupcyjne i oligarchów ${ }^{49}$. Takie oskarżanie drugiej strony i niedocenianie czynników sytuacyjnych to podstawowy błąd atrybucji.

Demonstracje na Majdanie Niepodległości w 2004 r. niewątpliwie istniały fizycznie. Był tłum, była kolektywna psychika, było poczucie niesprawiedliwości, były chęci zmiany, ale były też motywy finansowe (obietnice wsparcia finansowego ze strony USA i Zachodu w przypadku wygranej W. Juszczenki), była manipulacja rewolucyjną frazeologią, było „męczeństwo” Wiktora Juszczenki. Pytaniem jest: co pozostało? Badacze odnotowują pewne zmiany. M. Drozdowa pisze o pozytywnej zmianie postaw studentów wobec polityki, polityków, partii politycznych, władzy i wyborów ${ }^{50}$. I. Bilokoń donosi o obniżeniu poczucia socjalnej frustracji i makiawelizmu władz oraz o wzroście zaufania do demokracji i polityki. Zaznaczamy jednak, że te optymistyczne wyniki pochodzą z początku 2005 r. ${ }^{51}$ Czy dzisiaj termin ,pomarańczowa rewolucja”, to nie jest przypadkiem verbal fiction, czy może ma jakąś przedmiotową treść?

\section{„Pomarańczowa rewolucja” a wybory prezydenckie w 2010 roku}

Osoby, które „pomarańczowa rewolucja” wyniosła na szczyt władzy były żywo zainteresowane zachowaniem stanu metafizycznej świadomości „Majdanu”. Powód był prosty, ludzie utożsamiający się z Majdanem solidaryzowali się z władzą i jej działaniami ${ }^{52}$. Jednak już niedługo później, Majdan stał się dla wielu Ukraińców symbolem chaosu i kłótni ${ }^{53}$. Prawdziwymi okazały się rozważania W. Zlywkowa, gdy w swoim artykule umieścił on chińskie przysłowie: „kwiat dzisiejszego zwycięstwa

48 K. Skarżyńska, op. cit.

49 A. Tichołaz, op. cit.

50 М. Дроздова, Динаміка політичної свідомості студентів у прочесі виборчої кампанії 2004 року, „Соціальна психологія” 2005, nr 4, s. 32-43.

51 І. Білоконь, Політичні подї кінця 2004 року і соиіально-політичні настановлення молодi, „Соціальна психологія” 2005, $\mathrm{nr} 4$, s. 21-31.

52 A. Tichołaz, op. cit.

53 W. Jarzyński, op. cit. 
niesie w sobie kiełki jutrzejszej porażki" "54. Błąd był podstawowy, jak pisze A. Tichołaz, władza zamiast skupiać się na założeniach „,pomarańczowej rewolucji” terroryzowała społeczeństwo ,pomarańczową frazeologią”.

Rosnące niezadowolenie $\mathrm{z}$ prezydenta, kryzys ekonomiczny w państwie, doświadczenia związane z wyborami Krawczuka, Kuczmy tworzyły podczas wyborów w 2010 r. atmosferę wyboru „mniejszego zła”. Wybory prezydenta na Ukrainie, to nie wybór pewnej ideologii czy kierunku rozwoju, lecz tego faktu nie uświadamia znaczna część społeczeństwa mająca prawo głosu. Podstawowe założenia programów wyborczych kandydatów na prezydenta są bardzo podobne. Programy te nie wpadają w pamięć przeciętnemu obywatelowi, bo przedwyborcze obietnice rzadko kiedy są wcielane w życie. Dlatego też istotnej różnicy pomiędzy konkurentami politycznej elity nie było widać.

Uważamy, że uchybieniem Ukrainy podczas rodzenia się jej niepodległości było nieuchwalenie ustawy o lustracji politycznej. Ustawa taka miałaby zakazywać w ciagu pierwszej dekady zajmowanie ważnych funkcji politycznych byłym komunistom. Brak opozycji spowodował, że taka ustawa nie mogła zostać przegłosowana. Przy władzy pozostali ludzie ze starego systemu, liderzy byłego komunistycznego państwa, którzy zmienili sztandar swojej partii. Nawet dwadzieścia lat po upadku Związku Radzieckiego wyższe państwowe posady zajmują ludzie, których styl i zasady wywodzą się od komunizmu. W środkach masowego przekazu są oni jednak przedstawiani jako demokratyczni, proeuropejscy liderzy. W tym też kryje się jedna z przyczyn niepowodzenia ,pomarańczowej rewolucji”. Z tego punktu widzenia można analizować i nowych liderów kampanii wyborczej na prezydenta w 2010 r. Chociaż liczba kandydatów pretendujących na najwyższe stanowisko w państwie wynosiła 18, tak naprawdę liczyły się tylko dwie osoby: J. Tymoszenko i W. Janukowycz - wielki przegrany z 2004 r. Wyborcy bardzo negatywnie rozliczyli W. Juszczenkę za zmarnowanie szans i niespełnienie obietnic związanych z rozwojem kraju i zbliżeniem go do struktur europejskich. To na niego, a nie na J. Tymoszenko, „księżniczkę pomarańczowej rewolucji” spadła główna wina $^{55}$. Należało oczekiwać, że J. Tymoszenko po odłączeniu się od W. Juszczenki jako ambitny i pracowity polityk weźmie udział w tego-

54 В. Зливков, Психологія перемоги: віртуальні та реальні чинники, „Соціальна психологія" 2005, nr 3, s. 33-42.

55 J. Kucharczyk, Komentarz po wyborach prezydenckich na Ukrainie, http://www.isp.org.pl/files/5903920470568930001263894655.pdf, 2010. 
rocznych wyborach prezydenckich. Spore poparcie, którym cieszyła się J. Tymoszenko powodowało, że możliwość objęcia urzędu prezydenta pozostawała w zasięgu jej ręki. Tymoszenko dystansując się od niezrealizowanych obietnic „pomarańczowej rewolucji” odziedziczyła część elektoratu Juszczenki z wyborów $2004 \mathrm{r}$.

Obok dwóch głównych kandydatów w minionym roku pojawiły się dwaj „nowi” kandydaci: S. Tihipko i A. Jaceniuk. Specjaliści od marketingu politycznego, kreując ich wizerunki, akcentowali ich młodość oraz brak związków z aktualną władzą. Pokazywano ich jako reformatorów, przepełnionych siłą do kardynalnych zmian w państwie. Jednak informacje przedwyborcze nie wspominały, że obaj byli już u władzy w państwie (Tihipko jako minister ekonomiki, Jaceniuk jako marszałek sejmu), czyli mieli możliwość wpływać na wydarzenia w państwie. Właśnie dlatego bardzo wątpliwie wygląda ich brak powiązań z ówczesną władzą.

Przy zmianie władzy z ,pomarańczowych” na „biało-niebieskich” i odwrotnie większość ludzi pozostaje na swoich stanowiskach, dlatego można powiedzieć, że władza nie zmienia się - zmienia się tylko sztandar. Jest to zamknięte koło tych samych ludzi, którzy zmieniają polityczną orientację wyłącznie dla własnych korzyści. Jak wynika z ostatnich analiz wyborów prezydenckich i parlamentarnych, obywatele nie głosują oceniając konkretne wyniki pracy. Wybory stają się walką na percepcję, twórcami której są specjaliści od marketingu politycznego i reklamy. Tylko w ten sposób można wytłumaczyć fenomenalny wzrost popularności S. Tihipka $(13,05 \%)$ i A. Jaceniuka $(5,45 \%)$ (Oficjalne wyniki wyborów pierwszej tury, 2010).

Specjaliści od marketingu politycznego wyciagnęli wnioski z kampanii wyborczej z 2004 r. Wyraźnym przykładem jest zmiana wizerunku W. Janukowycza z regionalnego i twardego prorosyjskiego przedstawiciela przemysłowej części Ukrainy na polityka bardziej podobnego do swojego największego rywala w okresie jego świetności - W. Juszczenkę. Janukowycz nauczył się języka ukraińskiego, zaczął odwiedzać służbowo Unię Europejska, występował za współpracą nie tylko z Rosją, ale i ze Stanami Zjednoczonymi, złagodził krytykę w stosunku do swoich rywali. Taka transformacja wizerunku mogła przyciągnąć tych wyborców, którzy byli rozczarowani polityką wybranych przez nich przedstawicieli władzy. Zwiększyła się liczba jego zwolenników na Zachodzie i w Centrum. Zmienił się też wizerunek Juszczenki. W 2004 r. to był młody, silny, aktywny polityk, który swoją charyzmą mógł prowadzić ludzi do walki o demokrację. Wcześniejsza praca w parlamencie i Banku Państwowym 
przekonały obywateli o jego profesjonalizmie i posiadanych kwalifikacjach. Ludzie uwierzyli, że uda mu się szybko odbudować ukraińską gospodarkę. Zarazem był on patriotycznym liderem, który dbałby o interesy narodu. Po pięciu latach prezydentury wizerunek Juszczenki został totalnie zmieniony. Coraz częściej jest odbierany jako słaby proeuropejski polityk, któremu nie udało się zbudować fundamentu odpowiedzialnej władzy. Główna jego działalność skupiła się wokół funkcji reprezentujących państwo na arenie międzynarodowej. Te niekończące się podróże służbowe na otwarcie pomników, memoriałów, uczestnictwo w przedsięwzięciach kulturalnych. U wyborcy powstaje wyobrażenie, że prezydent nie interesuje się polityką wewnętrzną, gospodarką. To właśnie w czasie kryzysu ekonomicznego obywatele pragną widzieć efektywnego gospodarza, zaangażowanego w problemy wzrostu w sektorze przemysłowym i rolnictwie. Na dodatek brakuje wewnętrznej zgodności w szeregach partii politycznej Juszczenki. W porównaniu z Juszczenką, Janukowycz wygląda jak silny lider. Jego partia jest jednorodna, można z łatwością prześledzić jej strukturę. Wszystkie propozycje i działania przedstawicieli partii Regionów są inicjowane lub kontrolowane przez lidera, co dodaje mu autorytetu. Janukowycz jest postrzegany jako osoba, która więcej robi niż mówi. Juszczenko lubi natomiast zwoływać konferencje prasowe, na których przemawia godzinami, trudno jednak odnaleźć jakąś konstruktywną myśl w tych wypowiedziach. W odróżnieniu, Janukowycz nie włada talentem oratorskim, lecz zawsze zwraca uwagę na wyniki swojej pracy lub plany, które pragnie zrealizować. Prawdopodobnie dla wyborcy bardziej przyciagającym jest lider, posiadający zdolność angażowania wszystkich możliwych sił, aby osiagnnąć cel.

\section{Podsumowanie}

W 2004 r. masowe protesty ludności były spowodowane poczuciem niesprawiedliwości, wynikającym z fałszerstwa wyników wyborów. Celem tych działań była obrona konstytucyjnych praw poprzez zmianę reżimu „miękkiego autorytaryzmu” L. Kuczmy. Obranie kierunku na demokratyzację było głównym osiagnięciem Majdanu. Do władzy przyszła nowa elita polityczna. Ukraińcy otrzymali wolność słowa i demokratyczne wybory. Ale „piętą achillesową" wybranej przez naród władzy stała się jej chwiejność. Nastąpiło przejście od scentralizowanej kontroli do liberalnego braku odpowiedzialności. Seria permanentnych wyborów (lokalnych 
i parlamentarnych) nie pozwoliła osiagnąć planowanych efektów w zarządzaniu gospodarką. Funkcjonariusze przekształcili się z urzędników państwowych na polityków. Z perspektywy przeciętnego obywatela taki stan rzeczy może być odebrany jako zbliżony do anarchii.

Dlaczego podczas wyborów z 2010 r. Ukraińcy zagłosowali na kandydata, przeciwko któremu walczyli 5 lat temu? Media zachodnie oraz media ukraińskie skupione wokół Juszczenki w czasie kampanii wyborczej w 2004 r. akcentowały potrzebę demokratycznych przemian, których pierwszym elementem miały być „,przejrzyste” wybory. Skutkiem priorytetowego traktowania wartości zgodnych $\mathrm{z}$ duchem demokracji było zepchnięcie problemów ekonomicznych i społecznych na drugi plan. Po „nasyceniu się” wolnością słowa ludzie zaczęli odczuwać naturalne potrzeby związane z zapewnieniem sobie i swojej rodzinie materialnego dobrobytu $^{56}$. Populistyczne działania Janukowycza, przejawiające się w przedwyborczych obietnicach z 2010 r. oraz wizja lidera, który nie ,rzuca słów na wiatr", uzyskały poklask społeczeństwa, żądnego poprawy warunków społeczno-ekonomicznych. Jak wynika z danych CIA World Factbook i Nations in Transit, wskaźnik demokracji na Ukrainie w 2008 r. znacznie się poprawił i wynosi 4,39 w 2008 r., a warunki ekonomiczne wyrażone stopą wzrostu PKB spadły z 7,3\% w 2006 r. do 2,1\% w 2008 r. $^{57}$ Największy rywal Janukowycza $\mathrm{w}$ tych wyborach - J. Tymoszenko - pomimo równie dobrego wizerunku osoby pracowitej prawdopodobnie przegrała z powodu trudności, jakie napotkała podczas kierowania państwem w okresie kryzysu ekonomicznego.

Dalszy rozwój sytuacji politycznej na Ukrainie będzie uzależniony nie tylko od władzy rządzącej, ale także od działań opozycji, która utworzyła swój rząd. Wydarzenia polityczne na Ukrainie będą pełne napięć, sporów i podejrzeń. Prześledzenie tych zmian oraz rozwoju sytuacji politycznej po wyborach parlamentarnych może stanowić materiał na kolejny artykuł naukowy.

\section{Summary}

The events that took place in Ukraine in November and December 2004 entered history as the 'Orange Revolution.' The accuracy of the notion of 'revolution' in this case raises certain doubts, though. The absence of fundamental alterations in the social

56 В. Малинкович, op. cit.

57 O. Gorbaniuk, W. Razmus, D. Lewicka, op. cit. 
and political system of the state does not allow us to describe these events as revolutionary. The emergence of national conscience, political will and the qualitative change of the entire society's legal culture, all of which have obviously taken place there, are considered to be another step in Ukrainian evolution towards democracy.

Referring to the 'figure - ground' principle of the Gestalt theory it can be claimed that in 2004 the need for freedom of speech promoted democracy as 'the figure' against 'the ground' of economic needs that were fulfilled at a sufficient, albeit not the highest level. Having achieved its objective the society began to feel a deficiency of basic needs. When the 'orange' authorities failed to meet its expectations, the society lost confidence in them, and in the presidential elections of 2010 gave the 'white-and-blues' the chance to implement changes and build a competitive economy in the country. 
